\title{
Processable, Electroactive, and Aqueous Compatible Poly(3,4-Alkylenedioxypyrrole)s Through A Functionally Tolerant Deiodination Condensation Polymerization Supplementary Information
}

Ryan M. Walczak, James K. Leonard, and John R. Reynolds*

The George and Josephine Butler Polymer Research Laboratory, Center for Macromolecular Science and Engineering, Department of Chemistry, University of Florida, Gainesville, FL 32611.

\section{Experimental Section}

\begin{abstract}
Materials
All reagents were obtained either from Aldrich or Fisher Scientific, with the exception of ProDOP, which was obtained from Ciba Specialty Chemicals. All electrochemical solvents were distilled prior to use except for propylene carbonate, which was used as is. ITO-coated glass slides ( 7 × $50 \times 0.6 \mathrm{~mm}, 20 \Omega / \square)$ were obtained from Delta Technologies and were cleaned with ultrasound in acetone.
\end{abstract}

\section{Instrumentation}

NMR spectra were measured on a Gemini-300 FT-NMR, a VXR 300 FT-NMR, or a Mercury300 FT-NMR. High resolution mass spectrometry was performed on a Finnigan MAT 95Q Hybrid Sector or a Bruker APEX II FTICR. UV-vis-NIR spectra were recorded on a Varian Cary 5E UV-vis-NIR spectrophotometer. FTIR measurements were performed on a PerkinElmer Spectrum One FTIR outfitted with a LiTaO3 detector. Electrochemistry was performed on a Princeton Applied Research model 273A potentiostat/galvanostat. Electrochemical measurements were performed in a three-electrode cell configured with a Pt button $(0.02 \mathrm{~cm} 2)$ working electrode, a Pt flag counter electrode, and a $\mathrm{Ag} / \mathrm{Ag}+(10 \mathrm{mM}$ in TBAP/ACN) reference electrode, which was calibrated to the ferrocene/ferricinium redox couple. Electrochemistry on ITO/glass electrodes was performed in a three-electrode cell with ITO/glass as the working electrode, a Pt wire counter electrode, and a silver wire pseudoreference electrode. Contact to the ITO slides was made using conductive $\mathrm{Cu}$ tape (1131) purchased from 3M. Digital photographs were taken with a Canon PowerShot A75 digital camera by back illumination with a D50 (5000K) light source. Colorimetry was measured using a Minolta CS-100 Chroma Meter, during which samples were placed into an in-house fabricated dark box and illuminated from behind with a D50 (5000K) light source. Gel permeation chromatography (GPC) of all polymers was performed at $40{ }^{\circ} \mathrm{C}$ using a Waters Associates GPCV2000 liquid chromatography system with an internal refractive index detector (DRI) and two Waters Styragel HR-5E columns (10 $\mu \mathrm{m}$ PD, $7.8 \mathrm{~mm}$ ID, $300 \mathrm{~mm}$ length). The mobile phase used was HPLC grade THF at a flow rate of $1.0 \mathrm{~mL} / \mathrm{min}$. Injection volumes of $220.5 \mu \mathrm{L}$ were made at $0.05-0.07 \% \mathrm{w} / \mathrm{v}$ sample concentration. 
Retention times were calibrated to polystyrene standards from Polymer Laboratories (Amherst, MA)

\section{Synthesis}

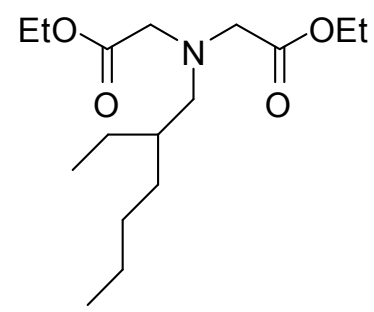

Diethyl $N$-(2-ethylhexyl)iminodiacetate (1a). To a 500-mL RB flask containing a stir bar and an argon atmosphere was added 2-ethyl-1-hexylamine (17.58 g, $136 \mathrm{mmol})$, anhydrous DMF $(200 \mathrm{~mL})$, anhydrous potassium carbonate $(46.99 \mathrm{~g}, 340 \mathrm{mmol})$, and ethyl bromoacetate $(50.00$ $\mathrm{g}, 299 \mathrm{mmol})$. The reaction was heated to $60{ }^{\circ} \mathrm{C}$, stirred overnight, and then cooled to room temperature. The mixture was poured into $\mathrm{Et}_{2} \mathrm{O}(200 \mathrm{~mL})$ and the organic layer was washed with $2 \times 200 \mathrm{~mL}$ DI water and $1 \times 100 \mathrm{~mL}$ of brine. The organic extract was then concentrated in vacuo and purified via vacuum distillation to yield $32.42 \mathrm{~g}(79 \%)$ of a clear oil. bp 111 $120^{0} \mathrm{C} @ 0.5 \mathrm{mmHg} ;{ }^{1} \mathrm{H} \mathrm{NMR}\left(300 \mathrm{MHz}, \mathrm{CDCl}_{3}\right): \delta 4.16(\mathrm{q}, 4 \mathrm{H}, \mathrm{J}=8.0 \mathrm{~Hz}), 3.52$ (s, J = $\left.2 \mathrm{~Hz}\right)$, $2.54(\mathrm{dd}, 2 \mathrm{H}, \mathrm{J}=7.0 \mathrm{~Hz}, \mathrm{~J}=3.7 \mathrm{~Hz}), 1.45-1.19(\mathrm{~m}, 9 \mathrm{H}), 1.27$ (t, 6H, J = 8.0 Hz), 0.89 (t, 3H, J $=6.7 \mathrm{~Hz}), 0.85(\mathrm{t}, 3 \mathrm{H}, \mathrm{J}=8.0 \mathrm{~Hz}) ;{ }^{13} \mathrm{C} \mathrm{NMR}\left(75 \mathrm{MHz}, \mathrm{CDCl}_{3}\right): \delta 171.7,60.5,58.6,55.7,37.7$, 31.1, 29.1, 24.3, 23.3, 14.5, 14.3, 10.9; HRMS (EI): Calcd for $\mathrm{C}_{16} \mathrm{H}_{31} \mathrm{NO}_{4}\left([\mathrm{M}]^{+}\right), 301.2253$, found $\mathrm{m} / z$, 301.2265; Anal. Calcd for $\mathrm{C}_{16} \mathrm{H}_{31} \mathrm{NO}_{4}$ : C, 63.75; $\mathrm{H}, 10.37 ; \mathrm{N}, 4.65 \%$, found: C, $63.85 ; \mathrm{H}, 10.79 ; \mathrm{N}, 4.95 \%$.<smiles>COC(=O)CN(CC(=O)OC)Cc1ccccc1</smiles>

Dimethyl 2,2'-(benzylazanediyl)diacetate (1b). This molecule was prepared as previously reported. ${ }^{1}$<smiles>CCCCC(CC)Cn1c(C(=O)OCC)c(O)c(O)c1C(=O)OCC</smiles>

Diethyl 1-(2-ethylhexyl)-3,4-dihydroxy-1H-pyrrole-2,5-dicarboxylate (2a). To a 250-mL RB flask containing an argon atmopshere and a stir bar, and outfitted with a reflux condenser was added ethanol (200 proof, $125 \mathrm{~mL})$ and sodium metal $(6.87 \mathrm{~g}, 299 \mathrm{mmol})$. When the evolution of hydrogen gas was observed to stop, the mixture was heated to $80{ }^{0} \mathrm{C}$ and a mixture of compound 1a $(30.00 \mathrm{~g}, 99.5 \mathrm{mmol})$ and diethyl oxalate $(14.34 \mathrm{~g}, 99.5 \mathrm{mmol})$ was added to the reaction. The reaction immediately became brown, and after refluxing for 45 minutes became a solid yellow chunk. Reflux was maintained for an additional 30 minutes and the reaction was 
cooled to room temperature. The yellow precipitate was filtered and washed with several portions of ethanol, then added to DI water $(500 \mathrm{~mL})$. The solution was acidifed to $\mathrm{pH} \sim 5$ by adding glacial acetic acid, where upon the solution became a milky liquid. The solution was extracted with $2 \times 200 \mathrm{~mL}$ of $\mathrm{Et}_{2} \mathrm{O}$, and the combined extracts were washed with $2 \times 100 \mathrm{~mL}$ DI water, 1 x $100 \mathrm{~mL}$ brine and dried over $\mathrm{Na}_{2} \mathrm{SO}_{4}$. The solvent was removed in vacuo to yield a brown oil which later solidified. The compound was purified via flash chromatography on silica gel $\left(1: 1=\mathrm{Et}_{2} \mathrm{O}\right.$ : Hexanes) to yield $17.33 \mathrm{~g}(49 \%)$ of an off-white solid. TLC $R_{f}=0.55$ (Silica Gel, 1:1 = Et ${ }_{2} \mathrm{O}$ : Hexanes); ${ }^{1} \mathrm{H}$ NMR $\left(300 \mathrm{MHz} \mathrm{CDCl}_{3}\right): \delta 7.77$ (br s, 2H), $4.46(\mathrm{~d}, 2 \mathrm{H}, \mathrm{J}=8.7$ $\mathrm{Hz}), 4.41$ (q, 4H, J = 8.0 Hz), $1.60(\mathrm{p}, 1 \mathrm{H}, \mathrm{J}=6.7 \mathrm{~Hz}), 1.40(\mathrm{t}, 6 \mathrm{H}, \mathrm{J}=8.0 \mathrm{~Hz}), 1.30-1.00(\mathrm{~m}$, $8 \mathrm{H}), 0.84(\mathrm{t}, 3 \mathrm{H}, \mathrm{J}=7.0 \mathrm{~Hz}), 0.80(\mathrm{t}, 3 \mathrm{H}, \mathrm{J}=8.0 \mathrm{~Hz}) ;{ }^{13} \mathrm{C} \mathrm{NMR}\left(75 \mathrm{MHz}, \mathrm{CDCl}_{3}\right): \delta 163.0$, 139.3, 111.4, 61.3, 50.1, 41.7, 30.1, 28.6, 24.5, 23.4, 14.6, 14.2, 10.8; HRMS (EI): Calcd for $\mathrm{C}_{18} \mathrm{H}_{29} \mathrm{NO}_{6}\left([\mathrm{M}]^{+}\right), 355.1995$, found $\mathrm{m} / z$, 355.1996; Anal. Calcd for $\mathrm{C}_{18} \mathrm{H}_{29} \mathrm{NO}_{6}$ : C, 60.83; $\mathrm{H}$, 8.22; N, 3.94; O, $27.01 \%$, found: C, 61.52; H, 8.53; N, $3.98 \%$.<smiles>COC(=O)c1c(O)c(O)c(C(=O)OC)n1Cc1ccccc1</smiles>

Dimethyl 1-benzyl-3,4-dihydroxy-1H-pyrrole-2,5-dicarboxylate (2b). This molecule was prepared as previously reported. ${ }^{1}$

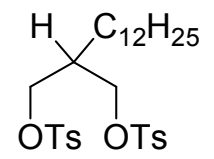

1,3-bis-(toluenesulfonato)-2-dodecylpropane (3c). To a 500-mL 3-neck RB flask outfitted with a reflux condenser, stopper, addition funnel, and containing an argon atmosphere and a stir bar was added diethyl malonate $(71.44 \mathrm{~g}, 446 \mathrm{mmol})$ and absolute ethanol $(250 \mathrm{~mL})$. To the mixture, sodium ethoxide ( $21 \mathrm{wt} \%$ in EtOH, $100 \mathrm{~mL}, 268 \mathrm{mmol}$ ) was added drop wise via the addition funnel over a period of 10 minutes, after which was added 1-bromodecane (22.13 g, $89.2 \mathrm{mmol}$ ). The reaction was refluxed for 48 hours, whereupon a white precipitate formed. After cooling to room temperature, the solvent was removed in vacuo and the concentrate was poured into DI water $(250 \mathrm{~mL})$ and extracted with $2 \times 250 \mathrm{~mL}^{\circ} \mathrm{Et}_{2} \mathrm{O}$. The combined organic extracts were dried over $\mathrm{Na}_{2} \mathrm{SO}_{4}$ and purified via vacuum distillation (bp $140{ }^{0} \mathrm{C} @ 1 \mathrm{mmHg}$ ) to yield $24.91 \mathrm{~g}(85 \%)$ of a clear oil, 2-dodecylmalonic acid diethyl ester.

To a flame-dried 500-mL RB flask outfitted with a reflux condenser, and containing a nitrogen atmosphere was added anhydrous THF $(225 \mathrm{~mL})$, and lithium aluminum hydride $(5.78 \mathrm{~g}, 152$ mmol). Then, the previous product, 2-dodecylmalonic acid diethyl ester (24.91 g, $76.1 \mathrm{mmol})$ dissolved into anhydrous THF $(25 \mathrm{~mL})$ was added drop-wise to the solution. Afterwards, the reaction was refluxed for 3 hours, cooled to room temperature, and carefully quenched with water and $1 \mathrm{~N} \mathrm{HCl}$. The mixture was extracted with 2 x $250 \mathrm{~mL}$ of ethyl acetate and concentrated in vacuo to yield $18.25 \mathrm{~g}$ (98\%) of a white solid 2-dodecylpropane-1,3-diol.

To a 250-mL RB flask containing a stir bar and an argon atmosphere was added 2dodecylpropane-1,3-diol (9.00 g, $36.8 \mathrm{mmol})$ and pyridine $(100 \mathrm{~mL})$. The mixture was chilled in 
an ice bath and $p$-toluenesulfonyl chloride $(17.55 \mathrm{~g}, 92.1 \mathrm{mmol})$ was added. The reaction was stirred for 3 hours, whereupon a white precipitate formed. The reaction was poured into DI water $(300 \mathrm{~mL})$ and extracted with $2 \times 200 \mathrm{~mL} \mathrm{Et}{ }_{2} \mathrm{O}$. The combined ether layers were washed with $1 \mathrm{~N} \mathrm{HCl}, 2 \times$ DI water, 1 x brine and then dried over $\mathrm{Na}_{2} \mathrm{SO}_{4}$. After concentrating in vacuo, the product was purified via flash chromatography on silica gel $\left(4: 1=\right.$ Hexane: $\mathrm{Et}_{2} \mathrm{O}$ gradient to 1:1 Hexane: $\mathrm{Et}_{2} \mathrm{O}$ ) to yield $13.37 \mathrm{~g}(66 \%)$ of the product as a clear oil. TLC $R_{f}=0.36$ (Silica Gel, 1:1 = Hexanes: $\mathrm{Et}_{2} \mathrm{O}$ );<smiles>COCCOCC[OH+]</smiles>

2-(2-methoxyethoxy)ethyl 4-methylbenzenesulfonate (3d). To a 250-mL RB flask containing a stir bar and an argon atmosphere was added triethylene glycol monomethyl ether $(10.00 \mathrm{~g}, 83.2$ mmol) and pyridine $(100 \mathrm{~mL})$. The reaction was chilled in an ice bath and then $p$ toluenesulfonyl chloride $(23.80 \mathrm{~g}, 125 \mathrm{mmol})$ was added. The reaction was allowed to stir for three hours, after which it was poured into DI water $(300 \mathrm{~mL})$ and extracted with $2 \times 150 \mathrm{~mL}$ of $\mathrm{Et}_{2} \mathrm{O}$. The combined organic layers were concentrated in vacuo to yield $17.25 \mathrm{~g}(76 \%)$ of the product as a pale yellow oil which was used without further purification. ${ }^{1} \mathrm{H}$ NMR $(300 \mathrm{MHz}$, $\left.\mathrm{CDCl}_{3}\right): \delta 7.78(\mathrm{dd}, 4 \mathrm{H}, \mathrm{J}=137 \mathrm{~Hz}, \mathrm{~J}=7.8 \mathrm{~Hz}), 3.68(\mathrm{~m}, 2 \mathrm{H}), 3.58(\mathrm{~m}, 2 \mathrm{H}), 3.48(\mathrm{~m}, 2 \mathrm{H}),(3.35$ $\mathrm{s}, 3 \mathrm{H}), 2.45(\mathrm{~s}, 3 \mathrm{H}) ;{ }^{13} \mathrm{C} \mathrm{NMR}\left(75 \mathrm{MHz}, \mathrm{CDCl}_{3}\right): \delta 145.0,133.11,133.09,130.0,128.1,71.9$, 70.8, 69.4, 68.8, 59.2, 21.8; HRMS (ESI FTICR): Calcd for $\mathrm{C}_{12} \mathrm{H}_{18} \mathrm{O}_{5} \mathrm{SNa}\left([\mathrm{M}+\mathrm{Na}]^{+}\right), 297.0773$, found $\mathrm{m} / \mathrm{z}, 297.0778$.<smiles>CCCCC(CC)Cn1c(C(=O)OCC)c2c(c1C(=O)OCC)OCCCO2</smiles>

Diethyl 7-(2-ethylhexyl)-2,3,4,7-tetrahydro-[1,4]dioxepino[2,3-c]pyrrole-6,8-dicarboxylate (4a). To a 250-mL RB flask containing a stir bar and an argon atmosphere was added compound 2a (8.00 g, $22.5 \mathrm{mmol})$, anhydrous DMF (125 mL), 1,3-dibromopropane (4.54 g, $22.5 \mathrm{mmol})$, and anhydrous potassium carbonate $(7.78 \mathrm{~g}, 56.3 \mathrm{mmol})$. The reaction was heated to $110{ }^{0} \mathrm{C}$ for 5 hours and then cooled to room temperature. The solution was poured into DI water $(250 \mathrm{~mL})$, extracted with $2 \times 100 \mathrm{~mL}$ of $\mathrm{Et}_{2} \mathrm{O}$, and the combined were washed with water, brine and dried over $\mathrm{MgSO}_{4}$. After concentrating in vacuo, the oil was purified via flash chromatography on silica gel $\left(3: 2=\right.$ Hexanes: $\left.\mathrm{Et}_{2} \mathrm{O}\right)$ to yield $5.82 \mathrm{~g}(65 \%)$ of a yellow oil. TLC $R_{f}=0.25$ (Silica Gel, 3:2 = Hexanes: $\left.\mathrm{Et}_{2} \mathrm{O}\right) ;{ }^{1} \mathrm{H}$ NMR $\left(300 \mathrm{MHz} \mathrm{CDCl}_{3}\right): \delta 4.60(\mathrm{~d}, 2 \mathrm{H}, \mathrm{J}=8.7 \mathrm{~Hz}), 4.33(\mathrm{q}, 4 \mathrm{H}, \mathrm{J}=$ $6.0 \mathrm{~Hz}), 4.15(\mathrm{dd}, 4 \mathrm{H}), 2.22(\mathrm{p}, 2 \mathrm{H}, \mathrm{J}=5.3 \mathrm{~Hz}), 1.53(\mathrm{p}, 1 \mathrm{H}, \mathrm{J}=6.7 \mathrm{~Hz}), 1.36(\mathrm{t}, 6 \mathrm{H}, \mathrm{J}=8.0 \mathrm{~Hz})$, $1.30-1.05(\mathrm{~m}, 8 \mathrm{H}), 0.84(\mathrm{t}, 3 \mathrm{H}, \mathrm{J}=8.0 \mathrm{~Hz}), 0.78(\mathrm{t}, 3 \mathrm{H}, \mathrm{J}=8.3 \mathrm{~Hz}) ;{ }^{13} \mathrm{C} \mathrm{NMR}(75 \mathrm{MHz}$, $\left.\mathrm{CDCl}_{3}\right): \delta 161.1,142.1,114.7,71.8,60.7,49.5,41.7,33.5,30.2,28.5,23.5,23.2,14.6,14.2$, 10.7; HRMS (EI): Calcd for $\mathrm{C}_{21} \mathrm{H}_{33} \mathrm{NO}_{6}\left([\mathrm{M}]^{+}\right), 395.2308$, found $m / z$, 395.2300; Anal. Calcd for $\mathrm{C}_{21} \mathrm{H}_{33} \mathrm{NO}_{6}$ : C, 63.78; H, 8.41; N, 3.54; O, $24.27 \%$, found: C, 64.27; H, 8.70; N, $3.60 \%$. 
<smiles>CC(=O)c1c2c(c(C(C)=O)n1Cc1ccccc1)OCCCO2</smiles>

Dimethyl 7-benzyl-2,3,4,7-tetrahydro-[1,4]dioxepino[2,3-c]pyrrole-6,8-dicarboxylate (4b). This molecule was prepared as previously reported. ${ }^{2}$

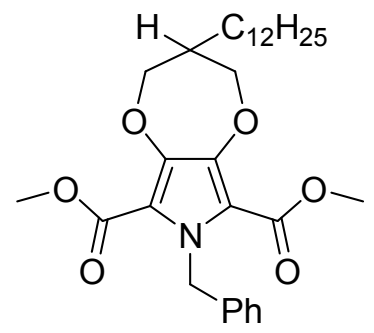

Dimethyl 7-benzyl-3-dodecyl-2,3,4,7-tetrahydro-[1,4]dioxepino[2,3-c]pyrrole-6,8dicarboxylate $(4 c)$.

To a 100-mL RB flask containing a stir bar and an argon atmosphere was added compound $\mathbf{2 b}$ $(2.21 \mathrm{~g}, 9.05 \mathrm{mmol}), 3 \mathrm{c}(5.00 \mathrm{~g}, 9.05 \mathrm{mmol})$, anhydrous potassium carbonate $(6.25 \mathrm{~g}, 45.3$ $\mathrm{mmol})$, and anhydrous DMF $(25 \mathrm{~mL})$. The reaction was heated to $95{ }^{0} \mathrm{C}$ and stirred for 4 hours, after which, it was cooled to room temperature. The mixture was poured into DI water $(200 \mathrm{~mL})$ and extracted with $2 \times 200 \mathrm{~mL} \mathrm{Et}_{2} \mathrm{O}$. The combined organic extracts were washed with brine, dried over $\mathrm{Na}_{2} \mathrm{SO}_{4}$, and concentrated in vacuo. The concentrate was purified via flash chromatography on silica gel $\left(3: 1=\right.$ Hexanes: $\left.\mathrm{Et}_{2} \mathrm{O}\right)$ to yield $1.55 \mathrm{~g}(33 \%)$ of a white solid. TLC $R_{f}=0.48$ (Silica Gel, 3:1= Hexanes: $\left.\mathrm{Et}_{2} \mathrm{O}\right) ;{ }^{1} \mathrm{H}$ NMR $\left(300 \mathrm{MHz}, \mathrm{CDCl}_{3}\right): \delta 7.26-6.94(\mathrm{~m}, 5 \mathrm{H})$, $5.94(\mathrm{~s}, 2 \mathrm{H}), 4.23(\mathrm{dd}, 2 \mathrm{H}, \mathrm{J}=13 \mathrm{~Hz}, \mathrm{~J}=4.0 \mathrm{~Hz}), 4.02(\mathrm{dd}, 2 \mathrm{H}, \mathrm{J}=13 \mathrm{~Hz}, \mathrm{~J}=7.3 \mathrm{~Hz}), 3.79(\mathrm{~s}$, $6 \mathrm{H}), 2.11(\mathrm{~m}, 1 \mathrm{H}), 1.50-1.22(\mathrm{~m}, 22 \mathrm{H}), 0.88(\mathrm{t}, 3 \mathrm{H}, \mathrm{J}=7.3 \mathrm{~Hz}) ;{ }^{13} \mathrm{C} \mathrm{NMR}\left(75 \mathrm{MHz}, \mathrm{CDCl}_{3}\right): \delta$ 161.2, 142.6, 139.2, 128.5, 127.0, 126.2, 114.0, 75.7, 51.9, 48.9, 42.2, 32.1, 29.89, 29.86, 29.84, 29.80, 29.5, 28.4, 27.3, 22.9, 14.3; HRMS (CI POS): Calcd for $\mathrm{C}_{30} \mathrm{H}_{43} \mathrm{NO}_{6}\left([\mathrm{M}]^{+}\right), 513.3090$, found $m / z, 513.3103$; Anal. Calcd for $\mathrm{C}_{30} \mathrm{H}_{43} \mathrm{NO}_{6}$ : C, 70.15; H, 8.44; N, $2.73 \%$, found: C, 71.03; $\mathrm{H}, 8.98 ; \mathrm{N}, 2.60 \%$.<smiles>COCCOCCOc1c(OCCOCCOC)c(C(=O)OC)n(Cc2ccccc2)c1C(=O)OC</smiles>

Dimethyl 1-benzyl-3,4-bis(2-(2-methoxyethoxy)ethoxy)-1H-pyrrole-2,5-dicarboxylate (4d). To a 250-mL RB flask containing a stir bar and an argon atmosphere was added compound $\mathbf{2 b}$ (6.00 g, $19.7 \mathrm{mmol})$, compound 3d (11.32 g, $41.3 \mathrm{mmol})$, anhydrous potassium carbonate (8.14 
g, $59.0 \mathrm{mmol})$, and anhydrous DMF $(50 \mathrm{~mL})$. The reaction was heated to $60{ }^{0} \mathrm{C}$ and stirred for 15 hours, after which it was poured into DI water $(200 \mathrm{~mL})$, and extracted with $2 \times 100 \mathrm{~mL}$ ethyl acetate. The combined organic extracts were washed with DI water $(100 \mathrm{~mL})$ and brine $(100$ $\mathrm{mL}$ ), then dried over $\mathrm{Na}_{2} \mathrm{SO}_{4}$. After concentrating in vacuo, the crude product was purified by flash chromatography on silica gel (ethyl acetate) to yield $7.33 \mathrm{~g}(73 \%)$ of a yellow oil. TLC $R_{f}$ $=0.44$ (Silica gel, ethyl acetate); ${ }^{1} \mathrm{H}$ NMR $\left(300 \mathrm{MHz}, \mathrm{CDCl}_{3}\right): \delta 7.35-6.91(\mathrm{~m}, 5 \mathrm{H}), 6.00(\mathrm{~s}$, 2H), $4.24(\mathrm{dd}, 4 \mathrm{H}), 3.80-3.78(\mathrm{~m}, 10 \mathrm{H}), 3.69(\mathrm{~m}, 4 \mathrm{H}), 3.56(\mathrm{~m}, 4 \mathrm{H}), 3.38(\mathrm{~s}, 6 \mathrm{H}) ;{ }^{13} \mathrm{C} \mathrm{NMR}$ $\left(75 \mathrm{MHz}, \mathrm{CDCl}_{3}\right): \delta 160.7,142.3,1390,128.4,126.9,126.0,116.5,73.9,72.1,70.6,70.3,59.1$, 59.1, 51.7, 51.7, 48.8; HRMS (ESI FTICR): Calcd for $\mathrm{C}_{25} \mathrm{H}_{35} \mathrm{NO}_{10} \mathrm{Na}\left([\mathrm{M}+\mathrm{Na}]^{+}\right), 532.2159$, found $m / z, 532.2146$; Anal. Calcd for $\mathrm{C}_{25} \mathrm{H}_{35} \mathrm{NO}_{10}$ : C, 58.93; H, 6.92; N, $2.75 \%$, found: C, $58.81 ; \mathrm{H}, 7.02 ; \mathrm{N}, 2.94 \%$.

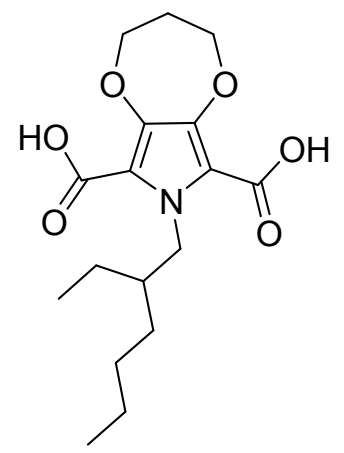

7-(2-Ethylhexyl)-2,3,4,7-tetrahydro-[1,4]dioxepino[2,3-c]pyrrole-6,8-dicarboxylic acid (5a). To a 500-mL RB flask containing a stir bar, reflux condenser, and an argon atmosphere was added compound 4a (12.99 g, $32.8 \mathrm{mmol}$ ), sodium hydroxide (6.56 g, $164 \mathrm{mmol})$, DI water (100 $\mathrm{mL})$, and acetone $(100 \mathrm{~mL})$. The slurry was bubbled with argon for 1 hour, then refluxed for 4 hours. After cooling to room temperature, the organic volatiles were removed in vacuo, and $100 \mathrm{~mL}$ of crushed ice was added to the brown aqueous mixture. The solution was carefully acidified to $\sim \mathrm{pH} 6$ with concentrated $\mathrm{HCl}$, and the resulting white precipitate was isolated via vacuum filtration. The solids were washed with several portions of DI water and air dried to yield $11.01 \mathrm{~g}(99 \%)$ of a white powder. ${ }^{1} \mathrm{H} \mathrm{NMR}\left(300 \mathrm{MHz}, \mathrm{CDCl}_{3}\right): \delta 4.85(\mathrm{dd}, 2 \mathrm{H}, \mathrm{J}=8.7 \mathrm{~Hz}$, $\mathrm{J}=2.0 \mathrm{~Hz}), 4.37-4.29(\mathrm{~m}, 4 \mathrm{H}), 2.39(\mathrm{p}, 2 \mathrm{H}, \mathrm{J}=5.7 \mathrm{~Hz}), 1.72(\mathrm{p}, 1 \mathrm{H}, \mathrm{J}=7.3 \mathrm{~Hz}), 1.39-1.03$ $(\mathrm{m}, 8 \mathrm{H}), 0.85(\mathrm{t}, 3 \mathrm{H}, \mathrm{J}=7.3 \mathrm{~Hz}), 0.83(\mathrm{t}, 3 \mathrm{H}, \mathrm{J}=8.0 \mathrm{~Hz}) ;{ }^{13} \mathrm{C} \mathrm{NMR}\left(75 \mathrm{MHz}, \mathrm{CDCl}_{3}\right): \delta 159.4$, 139.3, 113.6, 73.7, 49.8, 41.4, 33.5, 30.3, 28.7, 23.6, 23.3, 14.3, 11.0; HRMS (ESI FTICR): Calcd for $\mathrm{C}_{17} \mathrm{H}_{25} \mathrm{NO}_{6} \mathrm{Na}\left([\mathrm{M}+\mathrm{Na}]^{+}\right)$, 362.1580, found $\mathrm{m} / z$, 362.1574; Anal. Calcd for $\mathrm{C}_{17} \mathrm{H}_{25} \mathrm{NO}_{6}$ : C, 60.16; H, 7.42; N, $4.13 \%$, found: C, 60.17; H, 7.68; N, 3.60\%.<smiles>O=C(O)c1c2c(c(C(=O)O)n1Cc1ccccc1)OCCCO2</smiles>

7-Benzyl-2,3,4,7-tetrahydro-[1,4]dioxepino[2,3-c]pyrrole-6,8-dicarboxylic acid (5b). To a 250-mL RB flask containing a stir bar was added compound 5a (6.79 g, $19.7 \mathrm{mmol})$, sodium hydroxide (3.93 g, $98.3 \mathrm{mmol})$, DI water $(125 \mathrm{~mL})$ and methanol $(25 \mathrm{~mL})$. The reaction was deoxygenated by bubbling with argon for 30 minutes, after which the mixture was heated to 
reflux and stirred under argon for 4 hours. The organic volatiles were removed in vacuo and the resulting brown liquid concentrate was chilled by the addition of $\sim 100 \mathrm{~mL}$ of crushed ice. The reaction was then carefully acidified to $\mathrm{pH} \sim 6$ by the addition of concentrated $\mathrm{HCl}$. The resulting precipitate was then isolated via vacuum filtration, washed with several portions of DI water, and air-dried to yield $2.90 \mathrm{~g}(100 \%)$ of a white solid. ${ }^{1} \mathrm{H}$ NMR (300 MHz, DMSO-d6): $\delta$ $13-12$ (br s, 2H), $7.27-6.86(\mathrm{~m}, 5 \mathrm{H}), 5.90(\mathrm{~s}, 2 \mathrm{H}), 4.06(\mathrm{~s}, 4 \mathrm{H}), 2.11(\mathrm{~s}, 2 \mathrm{H}) ;{ }^{13} \mathrm{C} \mathrm{NMR}(75$ MHz, DMSO-d6): $\delta$ 161.4, 142.0, 139.5, 128.4, 126.8, 125.8, 114.2, 71.4, 47.4, 33.3.

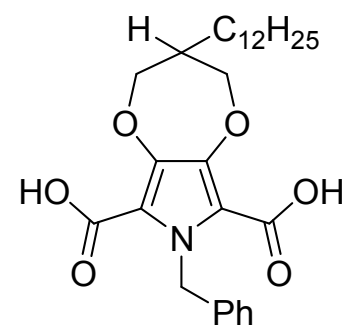

7-benzyl-3-dodecyl-2,3,4,7-tetrahydro-[1,4]dioxepino[2,3-c]pyrrole-6,8-dicarboxylic acid (5c). To a 250-mL RB flask containing a stir bar was added compound 4c (1.55 g, $3.02 \mathrm{mmol})$, sodium hydroxide $(0.60 \mathrm{~g}, 15.1 \mathrm{mmol})$, DI water $(50 \mathrm{~mL})$ and acetone $(25 \mathrm{~mL})$. The reaction was deoxygenated by bubbling with argon for 30 minutes, after which the mixture was heated to $80{ }^{\circ} \mathrm{C}$ and stirred under argon for 4 hours. The organic volatiles were removed in vacuo and the resulting brown liquid concentrate was chilled by the addition of $\sim 100 \mathrm{~mL}$ of crushed ice. The reaction was then carefully acidified to $\mathrm{pH} \sim 6$ by the addition of concentrated $\mathrm{HCl}$. The resulting precipitate was then isolated via vacuum filtration, washed with several portions of DI water, and air-dried to yield $1.47 \mathrm{~g}(100 \%)$ of a white solid. ${ }^{1} \mathrm{H}$ NMR (300 MHz, DMSO-d $)$ : $\delta$ $7.28(\mathrm{~m}, 5 \mathrm{H}), 5.89(\mathrm{~s}, 2 \mathrm{H}), 4.22-3.88(\mathrm{~m}, 4 \mathrm{H}), 2.09(\mathrm{~m}, 1 \mathrm{H}), 1.39-1.18(\mathrm{~m}, 22 \mathrm{H}), 0.85(\mathrm{t}, 3 \mathrm{H}$, $\mathrm{J}=6.3 \mathrm{~Hz}) ;{ }^{13} \mathrm{C}$ NMR (75 MHz, DMSO-d6): $\delta$ 162.5, 142.5, 140.3, 129.0, 126.7, 114.6, 110.0, 75.5, 32.0, 29.9, 29.7 - 29.6 (m), 27.9, 27.0, 22.8, 14.6; HRMS (ESI FTICR): Calcd for $\mathrm{C}_{28} \mathrm{H}_{40} \mathrm{NO}_{6}\left([\mathrm{M}+\mathrm{H}]^{+}\right), 486.2850$, found $m / z, 486.2872$.<smiles>COCCOCCOc1c(OCCOCCOC)c(C(=O)O)n(Cc2ccccc2)c1C(=O)O</smiles>

1-benzyl-3,4-bis(2-(2-methoxyethoxy)ethoxy)-1H-pyrrole-2,5-dicarboxylic acid (5d). To a 250-mL RB flask containing a stir bar was added compound 4d (6.00 g, $11.8 \mathrm{mmol})$, sodium hydroxide $(2.36 \mathrm{~g}, 58.9 \mathrm{mmol})$, DI water $(50 \mathrm{~mL})$ and acetone $(50 \mathrm{~mL})$. The reaction was bubbled with nitrogen for 30 minutes then refluxed for 3 hours under nitrogen. The organic volatiles were removed in vacuo, and the resulting concentrate was chilled by the addition of crushed ice. The mixture was acidified to $\mathrm{pH} 5$ via the addition of concentrated $\mathrm{HCl}$, and the resulting emulsion was extracted with $2 \times 150 \mathrm{~mL}$ of ethyl acetate. The combined organic extracts were washed with brine, dried over $\mathrm{Na}_{2} \mathrm{SO}_{4}$, and concentrated in vacuo to yield $4.78 \mathrm{~g}$ $(84 \%)$ of a dark oil. ${ }^{1} \mathrm{H}$ NMR $(300 \mathrm{MHz}$, acetone- $d 6): \delta 7.32-7.00(\mathrm{~m}, 5 \mathrm{H}), 6.12(\mathrm{~s}, 2 \mathrm{H}), 4.38$ 
$(\mathrm{m}, 4 \mathrm{H}), 3.78(\mathrm{~m}, 4 \mathrm{H}), 3.62(\mathrm{~m}, 4 \mathrm{H}), 3.49(\mathrm{~m}, 4 \mathrm{H}), 3.28(\mathrm{~s}, 6 \mathrm{H}) ;{ }^{13} \mathrm{C}$ NMR $(75 \mathrm{MHz}$, acetone$d 6): \delta 161.7,142.8,141.3,130.1,128.7,128.1,117.8,75.6,73.5,72.0,71.2,59.8,49.7$; HRMS (ESI FTICR): Calcd for $\mathrm{C}_{23} \mathrm{H}_{31} \mathrm{NO}_{10} \mathrm{Na}\left([\mathrm{M}+\mathrm{Na}]^{+}\right), 504.1846$, found $m / z, 504.1829$.<smiles>CCCCC(CC)Cn1c(I)c2c(c1I)OCCCO2</smiles>

7-(2-ethylhexyl)-6,8-diiodo-2,3,4,7-tetrahydro-[1,4]dioxepino[2,3-c]pyrrole (6a). To a 100$\mathrm{mL}$ RB flask containing a stir bar and outfitted with a pressure-equalizing addition funnel was added DI water $(25 \mathrm{~mL})$, potassium carbonate $(16.31 \mathrm{~g}, 118 \mathrm{mmol})$, and compound 5a. After a short time, the mixture became clear. To the addition funnel was added a premixed solution of $\mathrm{I}_{2}$ (3.06 g, $13.0 \mathrm{mmol})$, KI $(9.78 \mathrm{~g}, 58.9 \mathrm{mmol})$ and DI water $(25 \mathrm{~mL})$. The contents of the addition funnel were added drop wise (note a whitish precipitate gradually emerged) until a permanent brown color in the mother liquor was observed. Then, a small scoop of $\mathrm{NaHSO}_{3}$ was added and the solution became colorless. The emulsion was extracted with $2 \times 50 \mathrm{~mL}$ of DCM and the combined organic extracts were filtered through a short pad of basic alumina (with a $50 \mathrm{~mL}$ post filtration DCM wash). The solvent was removed in vacuo to yield $2.97 \mathrm{~g}(100 \%)$ of a yellow oil. Product was used immediately in the next procedure. ${ }^{1} \mathrm{H}$ NMR $\left(300 \mathrm{MHz}, \mathrm{CDCl}_{3}\right): \delta 5.30(\mathrm{~s}$, 2H), $4.04(\mathrm{~m}, 4 \mathrm{H}), 3.72(\mathrm{~d}, 1 \mathrm{H}, \mathrm{J}=7.7 \mathrm{~Hz}), 2.18(\mathrm{p}, 2 \mathrm{H}, \mathrm{J}=5.0 \mathrm{~Hz}), 1.91(\mathrm{~m}, 1 \mathrm{H}, \mathrm{J}=7.0 \mathrm{~Hz})$, $1.37-1.08(\mathrm{~m}, 8 \mathrm{H}), 0.88(\mathrm{~s}, 6 \mathrm{H}, \mathrm{J}=8.3 \mathrm{~Hz}) ;{ }^{13} \mathrm{C} \mathrm{NMR}\left(75 \mathrm{MHz}, \mathrm{CDCl}_{3}\right): \delta 142.2,125.1,72.8$, 59.4, 55.6, 40.6, 34.5, 30.6, 28.8, 24.4, 24.0, 23.2, 14.3, 11.3;<smiles>Ic1c2c(c(I)n1Cc1ccccc1)OCCCO2</smiles>

7-benzyl-6,8-diiodo-2,3,4,7-tetrahydro-[1,4]dioxepino[2,3-c]pyrrole (6b). Same procedure as 6a, except 5b was used. Product was isolated as $4.81 \mathrm{~g}(63 \%)$ a yellow solid. ${ }^{1} \mathrm{H}$ NMR (300 $\left.\mathrm{MHz}, \mathrm{CDCl}_{3}\right): \delta 7.31-6.99(\mathrm{~m}, 5 \mathrm{H}), 5.12(\mathrm{~s}, 2 \mathrm{H}), 4.08(\mathrm{~m}, 4 \mathrm{H}), 2.19(\mathrm{p}, 2 \mathrm{H}, \mathrm{J}=5.3 \mathrm{~Hz}) ;{ }^{13} \mathrm{C}$ NMR (75 MHz, $\left.\mathrm{CDCl}_{3}\right): \delta 142.9,137.3,128.8,127.69,126.6,116.2,72.8,59.3,55.1$; HRMS (ESI FTICR): Calcd for $\mathrm{C}_{14} \mathrm{H}_{14} \mathrm{I}_{2} \mathrm{NO}_{2}\left([\mathrm{M}+\mathrm{H}]^{+}\right), 481.9116$, found $m / z, 481.9129$

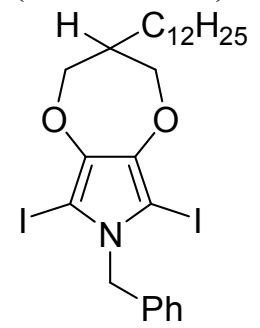


7-benzyl-3-dodecyl-6,8-diiodo-2,3,4,7-tetrahydro-[1,4]dioxepino[2,3-c]pyrrole (6c). Same procedure as 6a, except 5c was used. Product was isolated $(63 \%)$ as a yellow solid. ${ }^{1} \mathrm{H}$ NMR $\left(300 \mathrm{MHz}, \mathrm{CDCl}_{3}\right): \delta 7.34-7.10(\mathrm{~m}, 5 \mathrm{H}), 4.82(\mathrm{~s}, 2 \mathrm{H}), 3.98(\mathrm{dd}, 2 \mathrm{H}, \mathrm{J}=13 \mathrm{~Hz}, \mathrm{~J}=2.3 \mathrm{~Hz})$, $3.83(\mathrm{dd}, 2 \mathrm{H}, \mathrm{J}=13 \mathrm{~Hz}, \mathrm{~J}=7.3 \mathrm{~Hz}), 2.02(\mathrm{~m}, 1 \mathrm{H}), 1.48-1.22(\mathrm{~m}, 22 \mathrm{H}), 0.88(\mathrm{t}, 3 \mathrm{H}, \mathrm{J}=6.7$ $\mathrm{Hz}) ;{ }^{13} \mathrm{C}$ NMR $\left(75 \mathrm{MHz}, \mathrm{CDCl}_{3}\right): \delta 139.0,128.8,128.5,127.8,127.3,106.4,76.3,54.2,43.8$, $32.2,30.1,29.9(\mathrm{~m}), 29.6,27.5,27.4,22.9,14.4$;

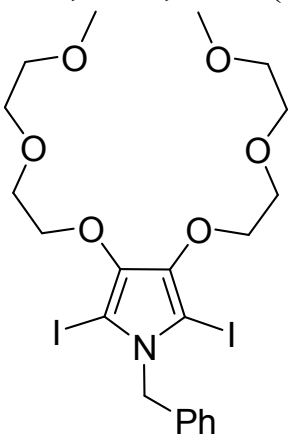

1-benzyl-2,5-diiodo-3,4-bis(2-(2-methoxyethoxy)ethoxy)-1H-pyrrole (6d). Same procedure as 6a, except 5d was used. Product was isolated (91\%) as a yellow oil. ${ }^{1} \mathrm{H}$ NMR $(300 \mathrm{MHz}$, $\left.\mathrm{CDCl}_{3}\right): \delta 7.35-6.98(\mathrm{~m}, 5 \mathrm{H}), 5.20(\mathrm{~s}, 2 \mathrm{H}), 4.16(\mathrm{~m}, 4 \mathrm{H}), 3.75(\mathrm{~m}, 4 \mathrm{H}), 3.65(\mathrm{~m}, 4 \mathrm{H}), 3.52(\mathrm{~m}$, 4H), $3.30(\mathrm{~s}, 6 \mathrm{H}) ;{ }^{13} \mathrm{C}$ NMR $\left(75 \mathrm{MHz}, \mathrm{CDCl}_{3}\right): \delta 144.2,139.4,130.3,129.0,127.9,106.1,73.5$, 72.0, 71.6, 64.6, 59.8, 56.6.

Typical procedures for the deiodination polymerization reactions. The following procedures represent typical procedures for the deiodination polymerization reactions.<smiles>CCCCC(CC)Cn1c(C(C)I)c2c(c1C(C)(I)I)OCCCO2</smiles>

Poly(7-(2-ethylhexyl)-6,8-diiodo-2,3,4,7-tetrahydro-[1,4]dioxepino[2,3-c]pyrrole) (7a). To a $25-\mathrm{mL}$ scintillation vial was added compound 6a $(253 \mathrm{mg}, 0.50 \mathrm{mmol})$. After flushing with nitrogen and capping, the vial was immersed into a $40{ }^{\circ} \mathrm{C}$ bath for 64 minutes, whereupon it became a black solid. The cap was removed and $10 \mathrm{~mL}$ of THF was added followed by the addition of excess hydrazine. The resulting yellow solution was precipitated into DI water, filtered under nitrogen over a $10 \mu \mathrm{M}$ Osmonics ${ }^{\mathrm{TM}}$ membrane filter, redissolved into THF, precipitated into hexanes, and filtered over a $10 \mu \mathrm{M}$ Osmonics ${ }^{\mathrm{TM}}$ membrane filter to yield 100 mg of a yellow solid. GPC (versus polystyrene): $M_{n}=21400 \mathrm{Da}, \mathrm{M}_{\mathrm{w}}=37500 \mathrm{Da}$. Yield (calculated via Equation 5-1): 79\%. 

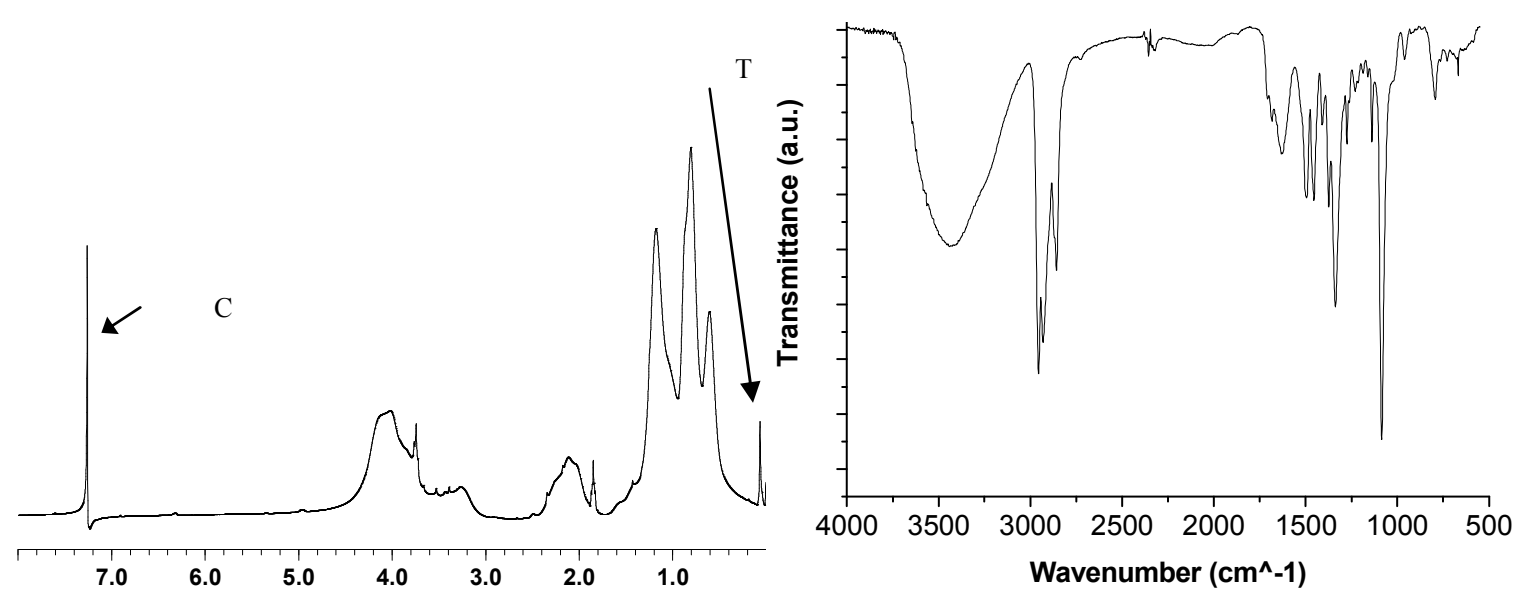

Figure S-1. Characterization data for 5a. Left: NMR $(300 \mathrm{MHz})$ in $\mathrm{CDCl}_{3}$. Right: FTIR (KBr disk) of a film drop cast from DCM.<smiles>Ic1c2c(c(C(I)I)n1Cc1ccccc1)OCCCO2</smiles>

7-benzyl-6,8-diiodo-2,3,4,7-tetrahydro-[1,4]dioxepino[2,3-c]pyrrole (7b). To a 100-mL RB flask was added compound $\mathbf{6 b}(4.81 \mathrm{~g}, 10.0 \mathrm{mmol})$ followed by flushing with nitrogen and capping. The flask was immersed into a $40{ }^{0} \mathrm{C}$ bath and after 24 hours, it became a black solid. The cap was removed and $25 \mathrm{~mL}$ of THF was added followed by the addition of excess hydrazine. The resulting yellow solution was precipitated into DI water, filtered under nitrogen over a $10 \mu \mathrm{M}$ Osmonics ${ }^{\mathrm{TM}}$ membrane filter, redissolved into THF, precipitated into hexanes, and filtered over a $10 \mu \mathrm{M}$ Osmonics ${ }^{\mathrm{TM}}$ membrane filter to yield $3.20 \mathrm{~g}$ of a yellow solid (NMR indicated presence of monomer). This solid was redissolved into DCM and precipitated into methanol. After filtration over a $10 \mu \mathrm{M}$ Osmonics $^{\mathrm{TM}}$ membrane, $1.49 \mathrm{~g}$ of a yellow solid was isolated. GPC (versus polystyrene): $\mathrm{M}_{\mathrm{n}}=3800 \mathrm{Da}, \mathrm{M}_{\mathrm{w}}=6000 \mathrm{Da}$. Yield (calculated via Equation 5-1): 41\%.

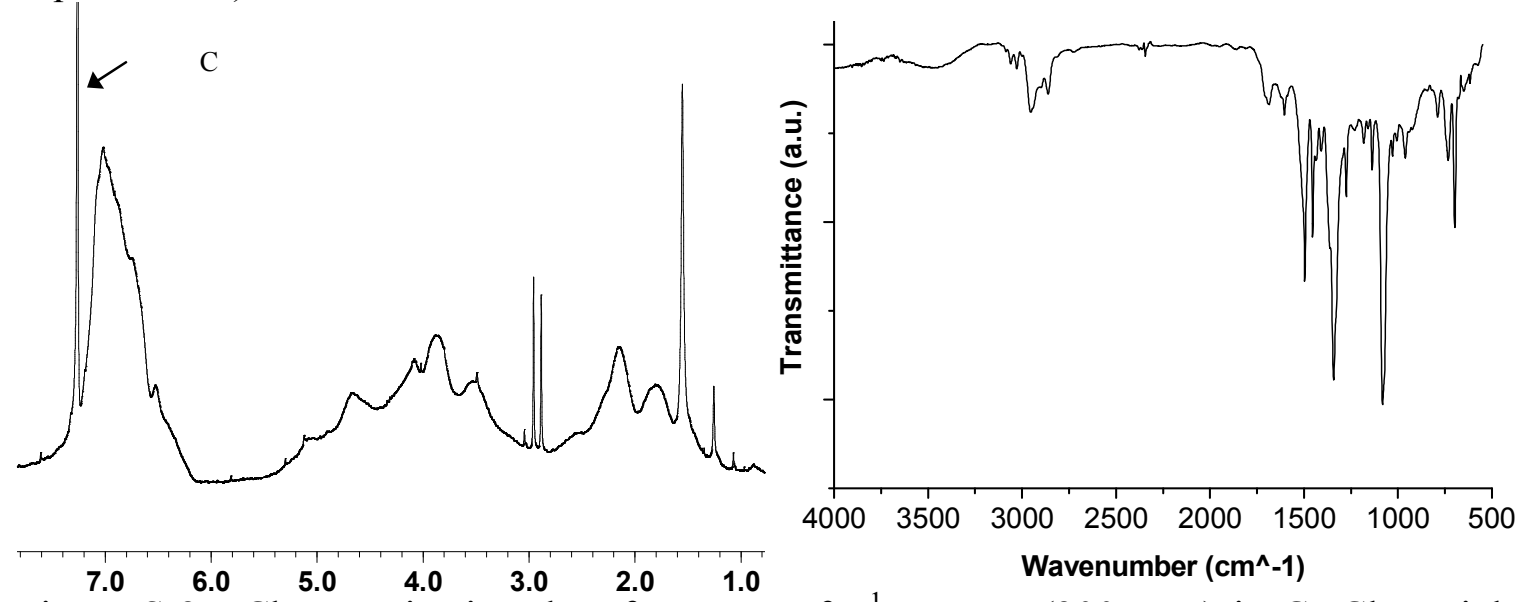

Figure S-2. Characterization data for 5b. Left: ${ }^{1} \mathrm{H}$ NMR $(300 \mathrm{MHz})$ in $\mathrm{CDCl}_{3}$. Right: FTIR (KBr disk) of a film drop cast from DCM. 


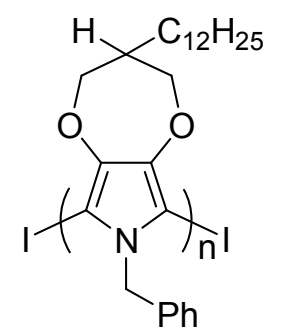

7-benzyl-3-dodecyl-6,8-diiodo-2,3,4,7-tetrahydro-[1,4]dioxepino[2,3-c]pyrrole (7c). To a 25$\mathrm{mL}$ scintillation vial was added compound $\mathbf{6 c}(492 \mathrm{mg}, 0.76 \mathrm{mmol})$ followed by flushing with nitrogen and capping after 1 week, it became a black solid. The cap was removed and $10 \mathrm{~mL}$ of THF was added followed by the addition of excess hydrazine. The resulting yellow solution was precipitated into methanol, filtered under nitrogen over a $10 \mu \mathrm{M}$ Osmonics ${ }^{\mathrm{TM}}$ membrane filter to yield $125 \mathrm{mg}$ of a yellow solid. GPC (versus polystyrene): $\mathrm{M}_{\mathrm{n}}=8700 \mathrm{Da}, \mathrm{M}_{\mathrm{w}}=15700 \mathrm{Da}$. Yield (calculated via Equation 5-1): 41\%.
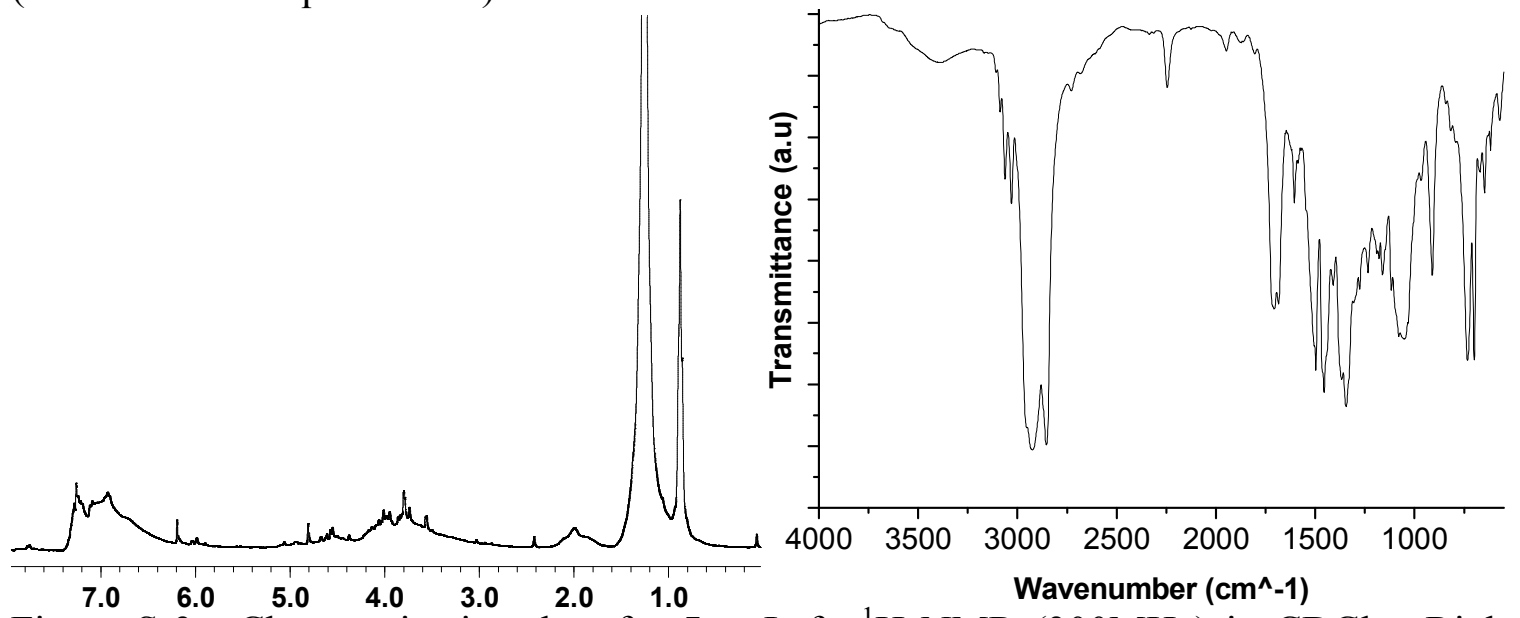

Figure S-3. Characterization data for 5c. Left: ${ }^{1} \mathrm{H}$ NMR $(300 \mathrm{MHz})$ in $\mathrm{CDCl}_{3}$. Right: FTIR $\left(\mathrm{NaCl}\right.$ disk) of a film drop cast from $\mathrm{CDCl}_{3}$.<smiles>COCCOCCOc1c(OCCOCCOC)c(C(I)(I)I)n(Cc2ccccc2)c1CI</smiles>

1-benzyl-2,5-diiodo-3,4-bis(2-(2-methoxyethoxy)ethoxy)-1H-pyrrole (7d). To a 100-mL RB flask was added compound 6d (3.03 g, $4.70 \mathrm{mmol})$ followed by flushing with nitrogen and capping. The flask was kept at room temperature and after 4 days, it became a black solid. The cap was removed and $25 \mathrm{~mL}$ of THF was added followed by the addition of excess hydrazine. The resulting yellow solution was precipitated into hexane and filtered under nitrogen over a 10 $\mu \mathrm{M}$ Osmonics ${ }^{\mathrm{TM}}$ membrane filter to yield $0.82 \mathrm{~g}$ of a tacky yellow-orange solid. GPC (versus polystyrene): $\mathrm{M}_{\mathrm{n}}=10300 \mathrm{Da}, \mathrm{M}_{\mathrm{w}}=17200 \mathrm{Da}$. Yield (calculated via Equation 5-1): 44\%. 

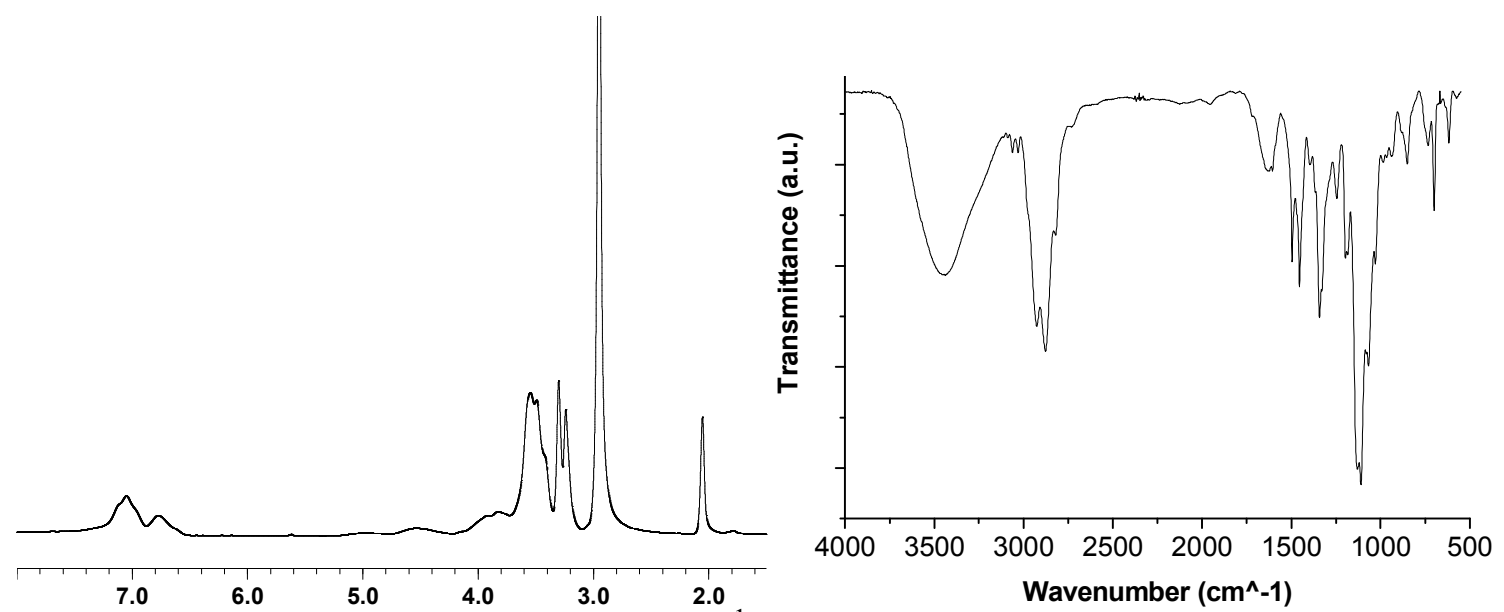

Figure S-4. Characterization data for 5d. ${ }^{1} \mathrm{H}$ NMR $(300 \mathrm{MHz})$ in acetone- $d 6$. Right: FTIR (KBr disk) of a film drop cast from DCM.

1. Merz, A.; Schropp, R.; Dotterl, E., Synthesis 1995, (7), 795-800.

2. Schottland, P.; Zong, K.; Gaupp, C. L.; Thompson, B. C.; Thomas, C. A.; Giurgiu, I.; Hickman, R.; Abboud, K. A.; Reynolds, J. R., Macromolecules 2000, 33, (19), 70517061. 